\title{
Journal of Congenital Cardiology - new, innovative and custom-made for congenital heart disease
}

\section{A. Graham StuartiD}

Welcome to the inaugural issue of the Journal of Congenital Cardiology. In this era of mass communication, social media and instant access data, how can we justify yet another scientific journal covering cardiology?

\section{Editorial}

Many of us find ourselves swamped with information at every level. Textbooks are out of date before they are printed, "expert" patients use internet search engines to glean information on rare conditions and end up knowing (or "believing" they know) more than many non-specialist clinicians and new research is reported by social media before papers are in print. Many of us receive tables of contents representing multiple journals and dozens of scientific papers every week. It is difficult to keep up!

However, despite this plethora of information, the system has significant limitations! Established, mainstream print journals tend to be dominated by large and expensive multicentre clinical studies or, alternatively, by very small basic science investigations that examine minutiae within carefully controlled environments. Arguably, both of which are outside of the day to day working environment of most clinicians. It is increasingly clear that "real world" data are needed to help interpret the results of the carefully selected multicentre trial. Moreover, in congenital heart cardiology, we look after patients who have a diverse range of anatomic defects of widely varying complexity and an age spectrum that extends from conception to old age. Many of our patients have a unique combination of dysfunctional anatomy and physiology. This makes large, prospective studies extremely challenging to carry out. Consequently, it can prove difficult to publish congenital heart research in mainstream journals.

In addition to issues related to congenital heart disease, existing subscription-based print journals are

Correspondence: graham.stuart@nhs.net

Bristol Royal Hospital for Children and Bristol Heart Institute, Level 7, Bristol

Royal Infirmary, Upper Maudlin Street, BS2 8HW Bristol, UK expensive which may put them out of reach of many readers who do not have access to large university or research budgets. Similarly, many print-based publications are unable to publish moving images and use still images as a facsimile of what they actually wish to show.

The Journal of Congenital Cardiology is the first open access journal to cover all aspects of fetal cardiology, paediatric cardiology and adult congenital heart disease. In this journal we hope to encourage innovation, test of concept papers and "out of the box" hypotheses that might take forward our specialty. We look forward to publishing "real world" studies and will encourage submissions from all subspecialties dealing with paediatric and congenital heart disease including (but not limited to) genetics, epidemiology, electrophysiology and interventions. The journal will publish expert reviews and the latest research articles. We will publish articles from related specialties and even from the "expert patient". We will encourage controversy when it stimulates and challenges our practice. We will have the facility to publish large data files which can be embedded into articles using the Figshare repository [1]. Within the context of a rigorous peer-review system we will encourage short series and case reports if they provide a unique or notable insight into the aetiology, diagnosis or management of a congenital heart condition.

Journal of Congenital Cardiology is published by the highly respected publisher, BioMed Central. By bringing together open access research and knowledge published in these areas, the Journal of Congenital Cardiology aims to become an essential resource for cardiologists, surgeons, general practitioners, researchers and healthcare professionals interested in congenital heart disease.

I hope you will enjoy reading our first issue and look forward to contributions in years to come. 
Acknowledgements

Not applicable

\section{Funding}

Not applicable

Availability of data and materials

Not applicable

\section{Authors' information}

Dr Stuart is Consultant Cardiologist in the Congenital Heart Centre, Bristol

Heart Institute and Bristol Royal Hospital for Children. He is Honorary Senior

Lecturer in Clinical Science, University of Bristol, UK.

\section{Competing interests}

The author of this article is the Editor-in-chief of this journal.

\section{Consent for publication}

Not applicable

Ethics approval and consent to participate

Not applicable

\section{Publisher's Note}

Springer Nature remains neutral with regard to jurisdictional claims in published maps and institutional affiliations.

Received: 1 May 2017 Accepted: 4 May 2017

Published online: 27 June 2017

\section{Reference}

1. Figshare - https://figshare.com/- Accessed 26 Jan 2017.

Submit your next manuscript to BioMed Central and we will help you at every step:

- We accept pre-submission inquiries

- Our selector tool helps you to find the most relevant journal

- We provide round the clock customer support

- Convenient online submission

- Thorough peer review

- Inclusion in PubMed and all major indexing services

- Maximum visibility for your research

Submit your manuscript at www.biomedcentral.com/submit 